\title{
Genre of transcription in aspect of composer's style (On the example of Oleksandr Nazarenko's creativity)
}

\author{
Pliuschenko Maksym Yu.
}

Lecturer of bayan and accordion of the 1st category at Kharkiv musical school for children no.5, Ukraine The research was conducted at the Department of Theory of Music of Kharkiv I. P. Kotliarevsky National

University of Arts, Ukraine

\begin{abstract}
:
This article considers theoretical and practical aspects of research of the transcription genre, grounds its stylistic properties, reliance on the model of other's performance, double authorship, and action of composer's interpretation. These issues are projected onto the timbre-texture complex in this genre as the most important factor of transcription.

The material of the research was the concert arrangement of F. Lips and the transcription of A. Nazarenko to one original source - the play «Shivering Leaves» by P. Norrbak. Specificity of the analyzed musical material proposed in this article is the comparison of two arrangements - F. Lips and A. Nazarenko - in order to identify the distinctions between them, as well as the revelation of the individual-style spectra of the transcriptions genre in A. Nazarenko's works. At this, it is noted that in creating the author's version, A. Nazarenko relied not on the original Waltz by P. Norrbak, but on the F. Lips' arrangement acting as a work model in this comparative analysis.

In the analysis of the two versions, different methods of research are used, besides the comparative one they are also interpretation, considering the problems of bayan performance; genre, and style, which characterize the compositional and dramatic features, genre-style specificity of musical exponents; organological, contributing to the research of the specificity of the instrument, here - bayan in the context of comparing its expressive possibilities in two plays. His research resulted in the identification of the principal distinctions in methods of artistic interpretation of two authors.
\end{abstract}

Keywords: artistic interpretation, transcription genre, timbre texture complex, bayan oeuvre, bayan artistic performance.

\section{Introduction}

The problems of artistic interpretation of a composer or a performer is a relevant field of modern musicology. As one of its facets we can name such genres as transcription or rendition, where composer's and performer's aspects of musical thinking intertwine. In the sphere of folk instruments, the relevance of these genres is caused by a fact that such vital process as extension of repertoire is largely achieved by usage of transcriptions, arrangements, renditions. Their specifics are caused by them pertaining to the field of secondary creativity, found on an artistic model, creation of its new composer's or performer's variant. These works preserve certain content of the original works, while bringing new artistic meaning.

The corpus of research on transcription as a genre in modern Ukrainian and foreign musicology is quite significant. Among the authors who contributed to this problem we may name M. Borysenko [2], M. Golomb [3], O. Zharkov [4], I. Palii [6], N. Prokina [7] etc. Transcription, just like plenty of genres, related to it, "works" with models of art, created by the "Other", thus it pertains to the sphere of composer's interpretation, marked by interaction of two systems, system of original work (primary source) and system of version (transcription). If we are to regard initial system as integral intonational idea (intonation, according to B. Asaf'ev, is a level of thinking in music [1]), we should note that in genres of composer's interpretation every level of this wholistic "idea-intonation" might become an object of re-intonation, reconsideration, interpretation. Its factors are mainly "non-specific" means of expression, that are the most 
receptive to new acoustic conditions, that are texture and timber. On the other hand, texture and timber become essential, therefore, special factors of transcription, if one is to understand the latter both as a process of interpretation-cognition of content's levels of the original and as its specific result.

In view of the foregoing we must note that it is necessary to include two approaches into methodology of analysis of transcriptions. The first one is founded on investigation of textural and timbral transformation of system of original as of relatively independent levels of musical form-content. The second one, obviously, should envisage their complex usage and interaction, that correlates to the very essence of such practice as transcription, since in order to fully reveal new timbre possibilities and characteristics of instruments that this transcription is created for, textural metamorphoses are necessary (quite often they are just inevitable), and vice versa.

Because of that, the author of a current research suggests his own methodology of comparative analysis of initial and derivative system, founded on interaction of timbre-texture unity. Regarding timbre and texture, these pivotal constituents of transcription's content and form, we must take into account that texture itself is a component of a synthetic nature, since it absorbs all the levels of expression of musical text. M. Borysenko states, that "texture, being co-dependent both with form and its elements, becomes a focus of all the processes of musical development, their systematic reflection, therefore, one of the prominent aspects of study of transcriptions" [2, p. 25]; "Textural intonation of original and of its version allows to comprehend textural re-intonation in transcription" as "supplementary non-specific mean of expression, capable of significant influence on specific levels of original musical content, that are melody, harmony, rhythm, due to the fact that sphere of intonational development affects them all" [2, pp. 25-26]. Set of means of musical expression incarnates in texture and timbre, therefore, each level of musical lexicon interacts with the factor of timbre, consequently, influencing it (directly or indirectly). Character of this interaction might be typical or individual, specific, according to the goals pursued by the interpreter.

Theoretical foundation of integration between texture and timbre into unified semantic and functional complex is set in the works of V. Tsukkerman, who uses a concept of "functionality of timbre-texture" [9, p. 342], as well as of O. Trofymchuk, who raises the questions of co-dependence of timbre with textural and structural elements in the scores of Ukrainian folk orchestras [8], of M. Borysenko, who marks correlation of musical components in the process of development of a work, their common, complex action as a synthetic interpretational phenomenon [2, p. 25].

The material, studied in this article, consists of two transcription of the same source, waltz by P. Norrbak "Shivering Leaves", made by F. Lips and O. Nazarenko. The latter composer, while doing his arrangement, used not the original version by P. Norrbak, but its interpretation by F. Lips, which in this case acquires role of a model for subsequent work.

The aim of an article is to reveal individually-stylistic spectra of O. Nazarenko's creativity as an arranger in the aspect of comparative analysis of complex intonational interaction of texture and timbre in the stated works.

O. Nazarenko's version of P. Norrbak's Waltz becomes a telling one for the style of Ukrainian musician as a composer. In this work O. Nazarenko operates several constituents of texture: melodic themes, harmonic voices, pedal, rhythm, timbre, as well as a set of performer's means of expression. Considering a research methodology, suggested in this research and founded on integration of elements forming texture, we shall regard several of them.

Synthetic characteristics of texture reveal themselves in timbre-harmony, and timbre-color becomes the leading factor of this interaction. Means of expression in O. Nazarenko's transcription play very important role. This is caused by the texture being saturated by additional harmonic voices, brought up from subtle voice-leading or re-composed by interpreter as new. This results in texture acquiring harmonic richness of sonority, it being condensed due to changes in harmony, as well as in "density of texture" and "mass of texture" [5]. The space between the voices becomes smaller, sonic space is filled by harmonic elements. Permanent increase in the quantity of voices might be discerned even in the Introduction. Another factor contributing to increasing role of harmonic factor on O. Nazarenko's version is harmonic pedal point. Overall, harmonic features significantly influence timbre as well. Sonority of bayan (button accordion) in this transcription is enriched by new expressive attributes.

Unlike O. Nazarenko, F. Lips in his arrangement of P. Norrbak's Waltz favors relatively light texture. Simultaneously, organ-like sonority of bayan is felt due to broad configuration of the chords, due to 
harmonic doubles in octaves, as well as in 10th and in 12th. The lower layer of the texture is emphasized due to the fact that the melody is located in the bass voice. And yet again we can see the intricate connection between timbre and the character of a texture.

If we are to further examine the interaction of timbre and texture, it is necessary to note the importance of the rhythm, syntaxis, performer's means of expression in this transcription.

Traits of waltz as a genre are revealed in these two transcriptions in different ways. F. Lips reduces bass part of bayan (left hand) to just simple typical for waltz rhythmic and harmonic formula, that is bass note and two chords; it allows him to lighten the texture and stress dance-like character. The tempo of the piece is quite fast, Tempo di Valse, whereas it is much more moderate in O. Nazareko's transcription, since in the latter case the texture is full of different elements, making the piece rather difficult both for execution and for listener's reception. As the music progresses, the author of this transcription makes melodic features of the bass voice more pronounced, sometimes adding chromaticism to it, which creates several passages of Romanza-like character (measures 112, 120, 128). It is worthy of noting that O. Nazarenko ignores glissandi-like movements in double notes, used by F. Lips, which allows the former one to stress the role of the bass. Its acquiring of melodic function allows the texture to be more flexible, polyphonic (with occasional imitations), at the same time somewhat belittles the role of typical waltz formula, marks it with the genre features of song or romanza. It naturally forces a part of harmonic layers to move to the right hand part. The typical formula of bass and two chords is obscured by tremolos as well as by the chords in the right hand, which makes the sound richer, the character filled with the features of brilliant dance, while dance movement gradually becomes general movement of music. The piece acquires flashy concert character.

Overall, transcription of O. Nazarenko becomes a concert interpretation of F. Lips' arrangement, which is caused by significant development of the textural component of music, directly influencing both timbre and semantics of the instrument, in this case - bayan. This is confirmed by performer's means of expression.

\section{Conclusion}

O. Nazarenko's version for bayan of a piece by P. Norrbak in its variant by F. Lips reveals its new artistic content, enriched by additional musical meanings, images, elements of composition, structure and semantics.

The main factors, changed in the transcription, are texture and timbre, as well as their synthetic interaction.

Timbre characteristics of transcriptions are largely influenced by all the components of a texture, which, in its turn, embody all the levels of original work's content: melodic themes, harmony, rhythm etc. Texture, being involved in the dialogue with timbre, becomes a complex and dynamic mean of expression.

The interaction with another textural components defines a role of timbre in music, its artistic meaning, character of timber's sonority.

Synthetic properties of timbre-texture embody in timbre-harmony, with timbre color being a definitive factor of this interaction. Harmonic means of expression on O. Nazarenko's interpretation play a leading role, since the interpreter fills the texture with additional harmonic voices, recreates them in "hidden" voice-leading or composes mew, adds harmonic pedal point. This results in new harmonic density of the texture, increase in the number of voices in harmonic vertical (as well as in density of texture, mass of texture and tightness of the sonority in the given timbre).

Among other means of interaction between texture and timbre we may name melody, rhythm, syntaxis, which define genre and style specifics of the instrument as a concert and virtuoso one, capable of creation of engaging theatrical, illustrative effects. They create new artistic image of Waltz by P. Norrbak, transform timbre and color, enrich it with continuous development. As a result of it, O. Nazarenko creates new version of this work, allowing fully demonstrate immense timbre potential of bayan (or accordion), technical capabilities of a performer, that are two main tasks of any concert interpretations.

\section{Notes}

Oleksandr Ivanovych Nazarenko is a bayan player from Kharkiv, Ukraine, Merited Art Worker of Ukraine, Professor, member on National All-Ukrainian Musical Union, teacher, performer and conductor.

Playing encore ("Igrayem na bis"). From the repertoire of Frydrych Lips: Works for bayan. Moscow: Muzyka, 2002. Page $38-42$.

Nazarenko O. I. Pieces, arrangements, transcriptions. Kharkiv: "Madrid", 2014. Pages 80 - 86. 


\section{References}

[1] Asaf'ev, B. (1971). Muzykal'naja forma kak process [Music Form as a Process]. Leningrad: Muzyka Press.

[2] Borysenko, M. Yu. (2004) Zhanr transkryptsiyi v systemi indyvidual'noho kompo-zytors'koho stylyu: dis. ...kandidata mistetstvoznavstva [Genre of transcription in the system of individual composer style. PhD Thesis]. Kharkiv.

[3] Golomb, M. (2000) Transkryptsiyi muzychnykh tvoriv u XIX st. Sproba typolohiyi na prykladi tvoriv Fryderyka Shopena [Transcriptions of musical works in the XIX century. An attempt at typology on the example of works by Frederic Chopin] // Fryderyk Shopen: zb. st. / red. Ya. Yakubovych. L'viv: SPOLOM Press.

[4] Zharkov, O. M. (1994) Khudozhniy pereklad v muzytsi: problemy i rishennya: avtoref. dis. ... kandidata mystetstvoznavstva [Art translation in music: problems and solutions: Synopsis for the PhD Thesis] / Nats. muz. akad. Ukrayiny im. P. I. Chaykovs'koho. Kyiv.

[5] Ignatchenko, G. I. (1984) O dinamicheskikh protsessakh v muzykal'noi fakture: avtoref. dis. ...kandidata iskusstvovedeniya [About dynamic processes in a musical invoice]. PhD's Thesis: IIFE im. M. T. Ril's'kogo AN Ukr.

[6] Palii, I. (2010) K opredeleniyu ponyatiya «transduktsiya» v muzykovedenii [To the definition of the concept of "transduction" in musicology] // Kognitivne muzikoznavstvo : zb. st. Vip. 29. Kharkiv: «S.A.M» Press.

[7] Prokina, N. V. (1989) Fortepiannaya transkriptsiya. Problemy teorii i isto-rii zhanra: avtoref. dis. ...kandidata iskusstvovedeniya [Piano transcription. The problems of theory and history of the genre: Synopsis for the PhD's Thesis] / Mos. gos. konservatoriya. Moscow.

[8] Trofymchuk, O. I. (2007) Tembrova evolyutsiya v ukrayins'kiy narodno-orkestroviy muzytsi: avtoref. dis. ...kandidata mystetstvoznavstva [Timbre evolution in Ukrainian folk and orchestral music: Synopsis for the PhD's Thesis]. Kyiv.

[9] Tsukkerman V. A. (1970) Muzykal'no-teoreticheskie ocherki i etyudy [Musical and theoretical essays and studies]. Vyp. 2. Moscow. 